\title{
Essential oil composition of Teucrium scordium $\mathbf{L}$.
}

\author{
KATAYOUN MORTEZA-SEMNANI ${ }^{*}$ \\ MAJID SAEEDI ${ }^{2}$ \\ MOHAMMAD AKBARZADEH ${ }^{3}$ \\ 1 Department of Medicinal Chemistry \\ Faculty of Pharmacy, Mazandaran \\ University of Medical Sciences, Sari, Iran \\ 2 Department of Pharmaceutics, Faculty \\ of Pharmacy, Mazandaran University of \\ Medical Sciences, Sari, Iran \\ ${ }^{3}$ Research Center of Natural Resources \\ of Mazandaran, Sari, Iran
}

\begin{abstract}
Composition of the essential oil obtained from dried flowering aerial parts of Teucrium scordium L. (Labiatae) was analyzed by GC and GC/MS. Fifty-six components were identified in the essential oil of $T$. scordium. The major constituents of the oil were $\beta$-caryophyllene $(22.8 \%),(E)-\beta$ farnesene $(10.4 \%)$, caryophyllene oxide $(8.6 \%), 1,8$-cineole $(6.1 \%)$ and $\beta$-eudesmol (5.1\%).
\end{abstract}

Keywords: Teucrium scordium (Labiatae), essential oil, $\beta$-caryophyllene, (E)- $\beta$-farnesene, caryophyllene oxide

Accepted October 12, 2007

The genus Teucrium (Labiatae) comprises 12 species, which are widely distributed in Iran $(1,2)$. T. scordium has anti-inflammatory, antipyretic, antiseptic, astringent, diaphoretic, diuretic, laxative, stimulant, tonic, emmenagogue, vermifuge and vulnerary activities (3). Unproven uses of this herb include the treatment of festering and inflamed wounds, bronchial ailments, diarrhea, fever, hemorrhoids, and intestinal parasites (4). In herbal medicine, it has already been used as tonic and for treatment of lung tuberculosis, jaundice and hemorrhoids and in external use for healing of wounds (5). Diterpenes, flavonoids, saponnins, tannins and volatile oil have been found in T. scordium (4-6). 6-Acetylteucjaponin B was recently isolated from T. scordium (7). A literature survey has shown that there is no report on the volatile constituents of T. scordium. The medicinal properties attributed to Teucrium scordium prompted us to investigate the chemical constituents of the oil of $T$. scordium for the first time.

\footnotetext{
*Correspondence, e-mail: ksemnani@yahoo.com
} 


\section{EXPERIMENTAL}

\section{Plant material}

Flowering aerial parts of T. scordium were collected in June 2005 from the suburb of Babolsar, Mazandaran province, North Iran, and identified by the Department of Botany, Research Center of Natural Resources of Mazandaran (Iran). A voucher specimen (herbarium No. 195) was deposited at the Herbarium of the Department of Botany, Research Center of Natural Resources of Mazandaran.

\section{Isolation of the essential oil}

The dried flowering aerial parts were subjected to hydrodistillation using a Clevenger-type apparatus for $4 \mathrm{~h}$. After separation, the oil was submitted to gas chromatographic analysis.

\section{Gas chromatography (GC)}

Gas chromatographic analysis was carried out on a Perkin-Elmer 8500 gas chromatograph with FID detector and a DB-5 capillary column $(30 \mathrm{~m} \times 0.25 \mathrm{~mm}$, film thickness $0.25 \mu \mathrm{m}$ ) (USA). The operating conditions were as follows: carrier gas helium with a flow rate of $2 \mathrm{~mL} \mathrm{~min}^{-1}$, split ratio 1:30. The oven temperature was programmed $4 \mathrm{~min}$ isothermal at $60^{\circ} \mathrm{C}$ and then $60-220^{\circ} \mathrm{C}$ at $4^{\circ} \mathrm{C} \mathrm{min}-1$, injector and detector temperatures were set at $240{ }^{\circ} \mathrm{C}$.

\section{Gas chromatography/mass spectrometry (GC/MS)}

GC/MS was carried out on a Hewlett Packard 6890 instrument programmed as follows: a DB- 5 capillary column $(30 \mathrm{~m} \times 0.25 \mathrm{~mm}$, film thickness $0.25 \mu \mathrm{m})$ (USA), $60{ }^{\circ} \mathrm{C}$ for $5 \mathrm{~min}$ and then up to $220^{\circ} \mathrm{C}$ at $4{ }^{\circ} \mathrm{C} \mathrm{min}-1$. The carrier gas was helium at a flow rate of

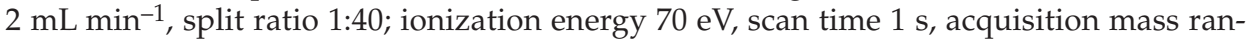
ge $m / z 40-400$.

\section{Identification of components}

The oil components were identified by their retention time, retention indices relative to $\mathrm{C}_{9}-\mathrm{C}_{28} n$-alkanes, computer matching with the WILEY275.L library and by comparison of their mass spectra with those of authentic samples or with data already available in the literature $(8,9)$. The concentration of the identified compounds was computed from the GC peak area without any correction factor.

\section{RESULTS AND DISCUSSION}

Hydrodistillation of the dried flowering aerial parts of T. scordium gave $0.9 \%(\mathrm{~m} / \mathrm{m})$ of light yellowish oil. As shown in Table I, fifty-six components were identified in this 


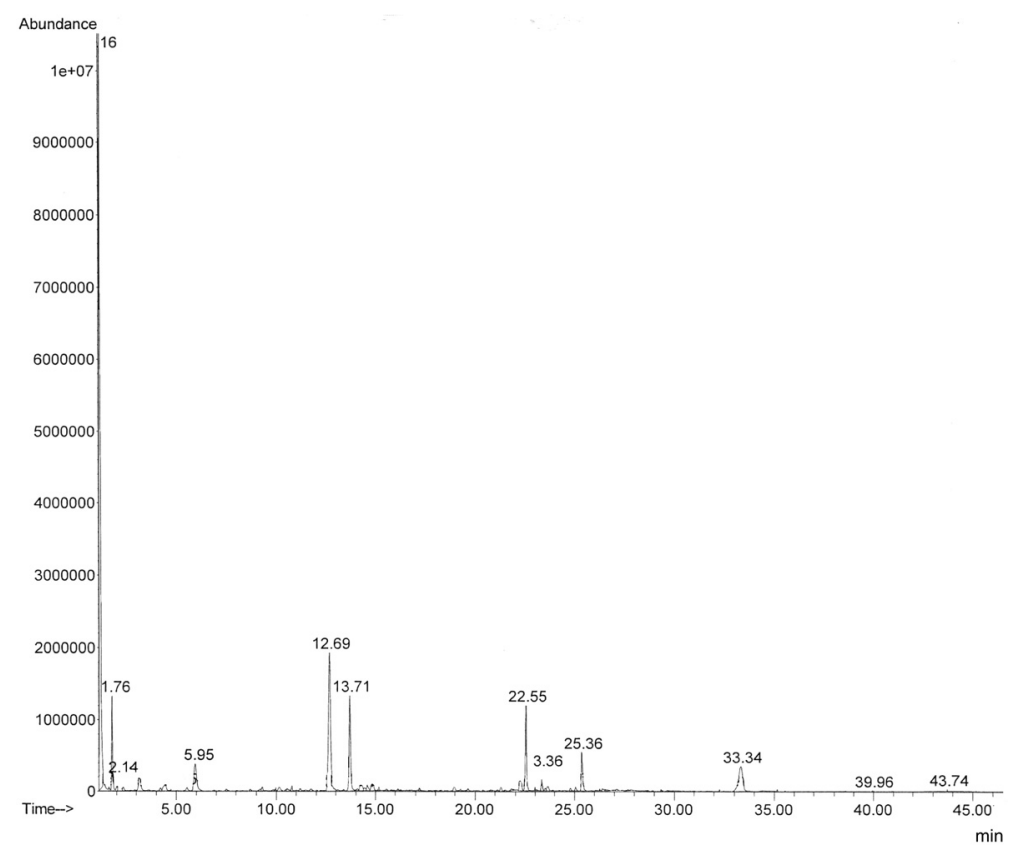

Fig. 1. Gas chromatogram of the essential oil of Teucrium scordium on DB-5 capillary column $(30 \mathrm{~m} \times 0.25 \mathrm{~mm}$; film thickness $0.25 \mu \mathrm{m})$.

oil, accounting for $97.9 \%$ of the total oil composition. The gas chromatogram of the oil on DB-5 capillary column is shown in Fig. 1 . The major constituents were $\beta$-caryophyllene $(22.8 \%)$, (E)- $\beta$-farnesene $(10.4 \%)$, caryophyllene oxide $(8.6 \%), 1,8$-cineole $(6.1 \%)$ and

Table I. Composition of the essential oil of Teucrium scordium $L$.

\begin{tabular}{rlcc}
\hline No. Component & RI $^{\mathrm{a}}$ & GC area $(\%)$ \\
\hline 1 & Pentanal & 708 & 0.1 \\
2 & (E)-2-Hexenal & 857 & 0.2 \\
3 & $\alpha$-Pinene & 941 & 3.3 \\
4 & Sabinene & 977 & 1.1 \\
5 & 1-Octen-3-one & 976 & 0.1 \\
6 & 1-Octen-3-ol & 980 & 0.2 \\
7 & $\beta$-Pinene & 981 & 3.2 \\
8 & Myrcene & 993 & 1.2 \\
9 & $p$-Cymene & 1027 & 0.9 \\
10 & Limonene & 1031 & 1.9 \\
11 & 1,8-Cineole & 1033 & 6.1 \\
12 & $n$-Nonanal & 1103 & 0.1 \\
13 & (E)-Tagetone & 1146 & 0.1 \\
\hline
\end{tabular}




\begin{tabular}{|c|c|c|c|}
\hline \multicolumn{2}{|c|}{ No. Component } & \multirow{2}{*}{$\begin{array}{c}\mathrm{RI}^{\mathrm{a}} \\
1166\end{array}$} & \multirow{2}{*}{$\frac{\text { GC area }(\%)}{1.2}$} \\
\hline 14 & Menthofuran & & \\
\hline 15 & $\alpha$-Terpineol & 1191 & 1.1 \\
\hline 16 & $(2 E, 4 E)$-2,4-Decadienal & 1319 & 0.4 \\
\hline 17 & $\alpha$-Copaene & 1353 & 1.1 \\
\hline 18 & n-Undecanol & 1372 & 0.1 \\
\hline 19 & $\beta$-Cubebene & 1378 & 1.2 \\
\hline 20 & (E)- $\beta$-Damascenone & 1386 & 0.8 \\
\hline 21 & $\beta$-Bourbonene & 1389 & 1.4 \\
\hline 22 & $\beta$-Elemene & 1393 & 1.1 \\
\hline 23 & Sativene & 1394 & 0.2 \\
\hline 24 & $(E)-\beta$-Damascone & 1416 & 2.3 \\
\hline 25 & $\beta$-Caryophyllene & 1421 & 22.8 \\
\hline 26 & $4,8-\beta$-Epoxy-caryophyllene & 1427 & 0.1 \\
\hline 27 & trans- $\alpha$-Bergamotene & 1437 & 0.6 \\
\hline 28 & Aromadendrene & 1443 & 1.2 \\
\hline 29 & (Z)- $\beta$-Farnesene & 1445 & 1.5 \\
\hline 30 & Khusimene & 1457 & 0.1 \\
\hline 31 & (E)- $\beta$-Farnesene & 1459 & 10.4 \\
\hline 32 & (E)-2-Dodecenal & 1468 & 0.1 \\
\hline 33 & Germacrene D & 1486 & 2.6 \\
\hline 34 & (E)- $\beta$-Ionone & 1491 & 1.1 \\
\hline 35 & $\beta$-Selinene & 1492 & 2.6 \\
\hline 36 & $\alpha$-Muurolene & 1502 & 1.2 \\
\hline 37 & $\delta$-Cadinene & 1525 & 1.4 \\
\hline 38 & $(E)-\gamma$-Bisabolene & 1533 & 0.1 \\
\hline 39 & Dodecanoic acid & 1569 & 0.1 \\
\hline 40 & Spathulenol & 1579 & 1.1 \\
\hline 41 & Caryophyllene oxide & 1585 & 8.6 \\
\hline 42 & Alloaromadendrene epoxide & 1642 & 0.7 \\
\hline 43 & Caryophylla-4(14),8(15)-diene-5-ol & 1643 & 0.3 \\
\hline 44 & epi- $\alpha$-Muurolol & 1644 & 1.2 \\
\hline 45 & Cubenol & 1649 & 1.1 \\
\hline 46 & $\beta$-Eudesmol & 1652 & 5.1 \\
\hline 47 & $\alpha$-Eudesmol & 1654 & 1.3 \\
\hline 48 & $\alpha$-Cadinol & 1655 & 1.2 \\
\hline 49 & Selin-11-en- $4 \alpha$-ol & 1662 & 1.1 \\
\hline 50 & Eudesma-4(15),7-dien-1 $\beta$-ol & 1690 & 0.1 \\
\hline 51 & $n$-Heptadecane & 1702 & 0.1 \\
\hline 52 & Longifoliol & 1717 & 0.1 \\
\hline 53 & $(2 E, 4 E)$-Farnesol & 1727 & 0.3 \\
\hline 54 & 14-Hydroxy- $\alpha$-muurolene & 1782 & 0.1 \\
\hline 55 & 6,10,14-Trimethyl-2-pentadecanone & 1845 & 0.1 \\
\hline & Hexadecanoic acid & 1984 & 0.1 \\
\hline Tota & & & \\
\hline
\end{tabular}

RI - Retention indices on DB-5 capillary column. 
$\beta$-eudesmol (5.1\%). T. scordium oil comprised monoterpenoids (13 compounds, $24.3 \%$ ), sesquiterpenoids (31 compounds, $71.9 \%$ ) and non-terpenoids (12 compounds, 1.7\%).

Caryophyllene oxide was reported as one of the main compounds of T. polium oil in both hydrodistillation and diethyl ether-pentane extraction methods (10). In 1990, the oils of six Teucrium species from the Iberian peninsula and the Balearic islands were characterized by high contents of aristolene, $\beta$-caryophyllene, $\alpha$-humulene, alloaromadendrene, caryophyllene epoxide and spathulenol, confirming the close morphological relationships between these species, as other authors have previously suggested (11). Caryophyllene oxide $(33.5 \%)$, linalool $(17.0 \%)$ and $\beta$-caryophyllene $(9.3 \%)$ were also identified as major compounds in the oil of T. orientale L. spp. orientale collected from the Fars province, Iran (12). We have already reported germacrene D (16.5\%), (Z)- $\beta$-farnesene $(12.2 \%)$, $\beta$-caryophyllene (10.5\%), $\alpha$-pinene $(9.1 \%)$ and $\delta$-cadinene $(7.4 \%)$ as the main compounds of T. chamaedrys collected in the Mazandaran province, North Iran (13). $\beta$-Caryophyllene was reported as the most abundant component in both $T$. orientale var. puberulens and $T$. chamaedrys subsp. lydium oils $-21.7 \%$ and $19.7 \%$, respectively (14).

According to our literature surveys, $\beta$-caryophyllene and caryophyllene oxide were reported as the main sesquiterpenes in many other Teucrium species, but in this research, in addition to $\beta$-caryophyllene and caryophyllene oxide, we also identified $(E)-\beta$-farnesene as the major compound. Since $\beta$-caryophyllene is an anti-inflammatory sesquiterpene (15), the results of this study may be used to confirm the anti-inflammatory activity of this plant.

\section{CONCLUSIONS}

Based on the above study, it may be summarized that the flowering aerial parts of $T$. scordium may be utilized for separation of the essential oil and a source of natural $\beta$-caryophyllene, (E)- $\beta$-farnesene and caryophyllene oxide.

\section{REFERENCES}

1. V. Mozaffarian, A Dictionary of Iranian Plant Names, Farhang Mo'aser Publishers, Tehran 1996, pp. 542-544.

2. K. H. Rechinger, Flora Iranica, Akademische Druck- U. Verlagsanstalt, Graz 1982, 150, pp. 33-35.

3. J. A. Duke, M. J. Bogenschutz-Godwin, J. De Cellier and P. A. K. Duke, Handbook of Medicinal Herbs, $2^{\text {nd }}$ ed., CRC Press, Boca Raton 2002, p. 762.

4. B. LaGow, PDR for Herbal Medicines, $3^{\text {rd }}$ ed., Thomson PDR Publications, Montvale 2004, pp. 865-866.

5. A. Zargari, Medicinal Plants, Vol. 4, Tehran University Publications, Tehran 1993, pp. 132-133.

6. J. A. Duke and S. M. Beckstrom-Sternberg, Handbook of Medicinal Mints, CRC Press, Boca Raton 2001, p. 337.

7. J. Coll and Y. Tandron, Isolation and structure elucidation of three neo-clerodane diterpenes from Teucrium fruticans L. (Labiatae), Phytochemistry 66 (2005) 2298-2303; DOI: 10.1016/j.phytochem.2005.07.003. 
8. N. W. Davies, Gas chromatographic retention indices of monoterpenes and sesquiterpenes on methyl silicone and carbowax 20M phases, J. Chromatogr. 503 (1990) 1-25; DOI: 10.1016/S00219673(01)81487-4.

9. R. P. Adams, Identification of Essential Oil Components by Gas Chromatography/Quadrupole Mass Spectroscopy, Allured Publishing Corporation, Carol Stream 2001, pp. 43-392.

10. D. Vokou and J. M. Bessiere, Volatiles constituents of Teucrium polium, J. Nat. Prod. 48 (1985) 498-499.

11. A. Velasco-Negueruela and M. J. Perez-Alonso, The volatiles of six Teucrium species from the Iberian Peninsula and the Balearic islands, Phytochemistry 29 (1990) 1165-1169; DOI: 10.1016/ 0031-9422(90)85421-B.

12. K. Javidnia and R. Miri, Composition of the essential oil of Teucrium orientale L. spp. Orientale from Iran, J. Essent. Oil Res. 15 (2003) 118-119.

13. K. Morteza-Semnani, M. Akbarzadeh and B. Rostami, The essential oil composition of Teucrium chamaedrys L. from Iran, Flavour Fragr. J. 20 (2005) 544-546; DOI: 10.1002/ffj.1479.

14. M. Kucuk, C. Gulec, A. Yasar, O. Ucuncu, N. Yayli, K. Coskuncelebi, S. Terzioglu and N. Yayli, Chemical composition and antimicrobial activities of the essential oils of Teucrium chamaedrys subsp. chamaedrys, T. orientale var. puberulens and T. chamaedrys subsp. lydium, Pharm. Biol. 44 (2006) 592-599; DOI: 10.1080/13880200600896868.

15. Y. Tambe, H. Tsujiuchi, G. Honda, Y. Ikeshiro and S. Tanaka, Gastric cytoprotection of the nonsteroidal anti-inflammatory sesquiterpene, beta-caryophyllene, Planta Med. 62 (1996) 469-470; DOI: $10.1055 / \mathrm{s}-2006-957942$.

\section{$S A \check{Z} E T A K$}

\section{Sastav eteričnog ulja biljke Teucrium scordium L.}

KATAYOUN MORTEZA-SEMNANI, MAJID SAEEDI i MOHAMMAD AKBARZADEH

Sastav eteričnog ulja iz osušenih nadzemnih dijelova biljke Teucrium scordium L. (Labiatae) u cvatu analiziran je pomoću GC i GC/MS. Identificirano je pedeset šest komponenata, a najvažniji sastojci ulja su $\beta$-kariofilen $(22,8 \%),(E)$ - $\beta$-farnesen $(10,4 \%)$, oksid kariofilen $(8,6 \%)$, (1,8-cineol) $(6,1 \%)$ i $\beta$-eudezmol $(5,1 \%)$.

Ključne riječi: Teucrium scordium (Labiatae), sastav eteričnog ulja, $\beta$-kariofilen, (E)- $\beta$-farnesen, oksid kariofilena

Faculty of Pharmacy, Mazandaran University of Medical Sciences, Sari, Iran Research Center of Natural Resources of Mazandaran, Sari, Iran 